Ann. Biol. anim. Bioch. Biophys., I976, 16 (5), 645-648.

\title{
EFFECT OF INVERSION OF ONE OR BOTH UTERINE HORNS ON FARROWING IN SOW
}

\author{
M. J. BOSC, A. LOCATELli, Agnès NiCOLlE \\ and F. du MESNIL du BUISSON (1) \\ with the technical assistance of Y. LEBRETON \\ Laboratoire de Physiologie de la Reproduction, \\ Centre de Recherches de Tours, I. N.R. A., \\ Nonzilly, 37380 Monnaie
}

In swine, a species of remarkable prolificacy, the piglets are born in several hours. While order of foetal position in one uterine horn corresponds to the order of birth, there is no determined sequence of expulsion between the two uterine horns (DzIUK and HARMON, I969). Uterine activity is regulated in such a way that all foetuses are usually expelled successively.

These regulations have been described in bilateral twin pregnancy in dog (KURDINOWSKI, Ig04) or in ewe (HINDSON, SCHOFIELID and TURNER, I968) ; in the latter species simultaneous presentation of two lambs at the cervix is a rare situation (Bosc, I975). In very prolific laboratory animals such as rat or rabbit, uterine contractions begin earlier near the ovary than near the cervix; at the end of labor, they become stronger towards the cervix (PoR'TER and Schofieid, I966; FUCHS, I969). In the farrowing sow, electromyographic activity, synchronous with variations in intrauterine pressure, spreads towards the cervix as well as towards the utero-tubal junction (ZEROBIN and SPORRI, I972). So we have attempted to determine the role of each uterine segment in sow by an indirect method, studying farrowing conditions in this species after the uterine horns have been inversed before mating.

\section{MATERIAL AND ME'THODS}

Large-White sows are divided into three groups. In the first group, one uterine horn is inversed so that the cervical region is in ovarian position and vice versa; the opposite horn is not changed. In group 2, one horn is inversed as above; the other is sectioned and the tissues sutured without inversing the horn. In group 3 , both uterine horns are inversed.

These modifications are carried out under general anesthesia; the genital tract is exteriorized by a medial subumbilical incision of about $15 \mathrm{~cm}$ in the abdomen. The "ligament latum uteri "

(1) Adresse actuelle: Station centrale de Physiologie animale, I.N.R.A., 78350 Jouy en Josas. 
is sectioned twice. The first section begins at a zone about $10 \mathrm{~cm}$ from the utero-tubal junction and ends at the vascular trunk formed by the main branches of the artery and the uterine vein. The second sections starts at about $5 \mathrm{~cm}$ from the inter-horn and ends at the first section on the other side of the vascular trunk. Hemostasis is obtained by electrocoagulation or by separated linen stitches. The uterus is then clamped, sectioned and inversed so that the ovarian side is in cervical position and vice versa. The endometrium and myometrium are sutured separately (cat-gut 5/I0 and 4/Io), and the clamps removed. The lips of the broad ligament are then sutured (Trinyl 3/Io). The genital tract is put back into the abdominal cavity. By this process, the vascular trunk, consisting of the branches of the artery and uterine vein, is turned $180^{\circ}$; and the number of large vessels sectioned is limited.

Sows are mated at the following and or 3 rd estrus and await farrowing. Following farrowing, the uterus is examined by slaughtering or cesarian. Some animals are studied during several pregnancies.

\section{RESULTS}

No fertility problem was observed in the 8 sows used in the experiment, and I7 pregnancies were obtained. These lasted a mean of II 4.5 days with extremes of III and II 7 days, which corresponds to control animals in the same herd. With the exception of one litter of 2 piglets, mean prolificacy was 9 .

\section{TABLE I}

Effect of inversion of one or both uterine horns on farrowing in sow

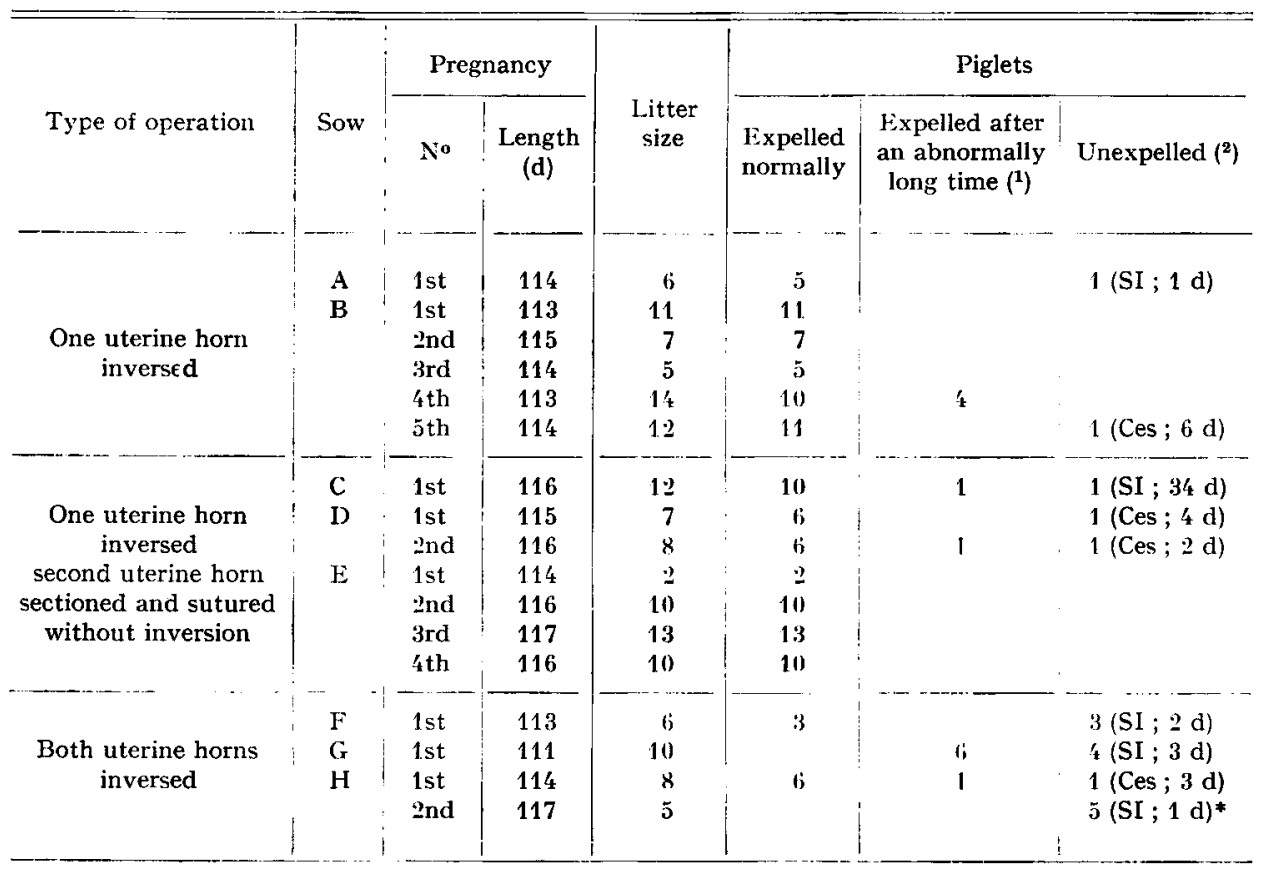

(1) Normal expulsion : in less than $8-10 \mathrm{~h}$; abnormal : in more than $8-10 \mathrm{~h}$.

${ }^{(2)} \mathrm{SI}$ : control at slaughter; Ces : observed by Cesarian. In days (interval between expulsion of fetus and observation of an empty uterus.

* Sow H was slaughtered after $-34 \mathrm{~h}$ of useless expulsive effort. 
Seven out of 8 sows had abnormal farrowing, either because births were spread over more than Io hours or because some foetuses were not expelled. The non-expulsion rate was higher when both horns were inversed. Results obtained for each animal are shown in the table; one can note 7 normal farrowings out of $\mathbf{I} 7$ which are due to two animals.

The unexpelled foetuses were always found in the inversed horns. There did not seem to be much constriction at the sutures. As at slaughter or cesarian, the three samplings done at midpregnancy showed that the fetuses had occupied both uterine horns.

Most of the piglets were born alive; those not expelled were found dead.

\section{DISCUSSION}

Inversion of one or both uterine horns caused abnormally long or incomplete birth in the majority of sows. Conversely, the normal fertility of operated sows implies that the mechanism of spermatozoa transport in the uterus had not been seriously damaged.

These two observations seem contradictory. The experiments of ALVAREZ (I948) on intestinal segment inversion may be cited as a comparison. They showed that liquids could still be transported while solids could not pass through the inversed segment. The situation in our experiments may be somewhat analogous.

Furthermore, blastocyst transport and distribution in the inversed uterine horns do not seem impaired since prolificacy is normal. This agrees with the common observation of embryo movement before day 13 of pregnancy since embryos are frequently observed to migrate from one horn to the other.

We do not know why some foetuses are blocked after our operation. It is difficult to imagine preferential activation of myometrial cells situated near the cervix because they are far away from the corpora lutea. In fact, corpus luteum regression is a prerequisite for farrowing in sow (Bosc, du MeSNIL, du Bursson and Locateli, I974), and no privileged relation between a uterine horn and an ipsilateral ovary can be shown at this time (STRYKER and DzIUK, I975).

Our results suggest that it may exist a muscular or a nervous system of regulation in the sow uterus which permits an ordely myometrial activity necessary to normal labor. Same other observations of an activity gradient between the ovarian and cervical zones in other species (REYNOLDS, I965) confirm this supposition.

Rę̧u pour publication en décembre 1975.

\section{RÉSUMÉ \\ EFFET DE L'INVERSION D'UNE OU DES DEUX CORNES UTÉRINES SUR IA MISE BAS DE LA TRUIE}

L'inversion des cornes utérines n'empêche pas l'établissement de gestations normales (I7 gestations chez 8 truies avec 9 jeunes par portée; durée moyenne de la gestation II4,5 jours). Par contre, l'expulsion des porcelets est fortement perturbée : après inversion des deux cornes 
utérines, au cours de 4 gestations, sur 29 porcelets 9 sont nés normalement, 7 après un temps anormalement long, I3 n'ont pu être expulsés.

Il semble donc exister un système de régulation musculaire ou nerveux permettant une ordonnance des contractions du myomètre nécessaires à une mise bas normale.

\section{REFERENCES}

Alvarez W. C., I948. Introduction to gastroenterology. P. B. HoEBeR Ed., New York, U.S. A.

Bosc M. J., du Mesnil du Buisson F., Locatelli A., I974. Mise en évidence d'un contrôle foetal de la parturition chez la Truie. Interactionș avec la fonction lutéale. C.R. Acad. Sc., Paris, Sér. I), 278, I5O7-I51O.

Bosc M. J., I975. Décider du jour de la mise bas n'est plus impossible. L'élevage, 39, 29-34.

Dziuk P. J., Harmon B. G., 1969. Succession of fetuses at parturition in the pig. Am. J. Vet. Res. 30, 4I9-421.

Fuchs A. R., I969. Uterine activity in late-pregnancy and during parturition in the rat. Biol. Reprod., 1, 344-353.

Hindson J. C., Schofield B. M., Turner C. B., ig68. Parturient pressures in the ovine uterus. J. Physiol., 195, I9-28.

Kurdinowski E. M., I904. Cited by F. M. A. Marshall and J. C. Moir in Marshall's Physiology of Reproduction, Parkes Ed., Cambridge, Longmans, Lond. U. K., 2, 496-524.

Porter D. G., Schofield B. M., I966. Intra-uterine pressure changes during pregnancy and parturition in rabbits. J. Endocr., 36, 291-299.

Reynolds S. R. M., I965. Physiology of the uterus. Hafner Publish. Company, New York.

Stryker J. L., Dziuk D. J., I975. Effects of fetal decapitation on fetal development, parturition and lactation in pigs, J. Anim. Sci., 40, 282-287.

Zerobin K., Sporri H., I972. Motility of the bovine and porcine uterus and Fallopian tube. Adv. Vet. Sc. Comp. Sc., 16, 303-354. 